\title{
CREATING THE NARRATIVE ON THE COSSACKS' HISTORY OF THE CIVIL WAR ERA IN THE SOUTH OF RUSSIA IN THE SYSTEM OF THE SOVIET IDEOLOGY OF THE 1920s - 1930s
}

\author{
Vasilina S. Klopikhina \\ Stavropol State Pedagogical Institute, Stavropol, Russian Federation
}

\begin{abstract}
Introduction. The article is devoted to the problem of forming the narrative on the history of the Don, Kuban and Terek Cossacks during the Civil war in the system of Istparts (Commissions on the history of the October revolution and the Russian Communist Party (Bolsheviks)) of the North Caucasus. The experts had not only the task to write a "different" history of modern times, but also to form a historical narrative, which was to reflect the interpretation of events permitted by the authorities as the basis for a new model of historical memory. Creating thenarrative in the operation system of Istparts determined the principles of selecting material and formulating key research issues. Methods and materials. The study is based on the methodology of "new local history". The author analyzes local historical narratives as images of the past created by Istparts of the North Caucasus with the help of discursive analysis. Analysis. The paper analyzes the interpretation of the Cossacks' history in the period of the socio-political crisis. It was found that in the 1920s the attention of researchers was focused on the search for class differentiation and struggle in the Cossacks' history. As a result, local historical narratives present an original interpretation of the Cossack stratification, which demonstrates the authors' desire to present the history of the Cossacks in accordance with the methodological instructions of the Commission on the history of the October Revolution and the Russian Communist Party (Bolsheviks). At the same time, they reflect judgments that are not limited to the ideological paradigm. This is due to the fact that in local historical narratives it was not always possible to combine the peculiarities of the historical process in the region with the proposed scheme and settings of the center. In the 1930s, there was a change in substantial aspects of constructing a new model of historical memory and historical narrative as its basis associated with the assertion of Stalin's sole power. Published works were publicly criticized and banned. The authors of such works were repressed in the era of the Great terror. At this time there appeared new ideological interpretations of the Cossacks' history. Since 1936, the political campaign "for the Soviet Cossacks" had been reflecting in creating the narrative in the system of Istparts. Results. Scientific analysis of sources and coverage of complexity and ambiguity of the historical process in the region were replaced by simple but "correct" ideological statements. With the help of interpreting the past focusing research attention on class stratification and explanation of the Cossacks' place in the history of the Civil war a new image of the Cossacks was formed in public consciousness.
\end{abstract}

Key words: istpart, historical memory, historical narrative, Soviet ideology, North Caucasus, history of the Cossacks, civil war.

Citation. Klopikhina V.S. Creating the Narrative on the Cossacks' History of the Civil War Era in the South of Russia in the System of the Soviet Ideology of the 1920s - 1930s. Vestnik Volgogradskogo gosudarstvennogo universiteta. Seriya 4. Istoriya. Regionovedenie. Mezhdunarodnye otnosheniya [Science Journal of Volgograd State University. History. Area Studies. International Relations], 2019, vol. 24, no. 4, pp. 135-147. (in Russian). DOI: https://doi.org/10.15688/jvolsu4.2019.4.12

\section{СОЗДАНИЕ НАРРАТИВА ПО ИСТОРИИ КАЗАЧЕСТВА ЭПОХИ ГРАЖДАНСКОЙ ВОЙНЫ НА ЮГЕ РОССИИ В СИСТЕМЕ СОВЕТСКОЙ ИДЕОЛОГИИ 1920-1930-х ГОДОВ}

\author{
Василина Сергеевна Клопихина
}

Ставропольский государственный педагогический институт, г. Ставрополь, Российская Федерация 
Аннотация. Введение. Статья посвящена проблеме формирования нарратива по истории казачества Дона, Кубани и Терека периода Гражданской войны в системе работы истпартов Северного Кавказа. Перед истпартами стояла не только задача написания «другой» истории новейшего времени, но и формирования исторического нарратива, который должен был отражать разрешенную властью интерпретацию событий как основу новой модели исторической памяти. Создание нарратива в системе деятельности истпартов определило принципы отбора материала и постановку ключевых исследовательских вопросов. Meтоды u мamepuaлbl. Изучение проводится автором на основе методологии «новой локальной истории». Локальные исторические нарративы как созданные истпартами Северного Кавказа образы прошлого анализируются с помощью дискурсивного анализа. Анализ. Проведен анализ интерпретации истории казачества в период социально-политического кризиса. Установлено, что в 1920-е гг. фокус внимания исследователей был сосредоточен на поиске классовой дифференциации и борьбы в истории казачества. Вследствие этого в локальных исторических нарративах представлена оригинальная трактовка расслоения казачества, которая демонстрирует стремление авторов представить историю казачества в соответствии с методологическими инструкциями центрального Истпарта. Одновременно в них нашли отражения суждения, не ограниченные идеологической парадигмой. Это обусловлено тем, что в локальных нарративах не всегда удавалось совместить особенности развития исторического процесса в регионе с предлагаемой схемой и установками центра. В 1930-е гг. произошло изменение содержательных аспектов конструирования новой модели исторической памяти и исторического нарратива как ее основы, связанное с утверждением единоличной власти И.В. Сталина. Изданные работы были публично раскритикованы и запрещены, а их авторы в эпоху Большого террора репрессированы. В это время появились новые идеологические интерпретации истории казачества. С 1936 г. при создании нарратива в системе истпартов нашла отражение политическая кампания «за советское казачество». Результаты. Научный анализ источников и освещение сложности и неоднозначности исторического процесса в регионе подменялись простыми, но «правильными» идеологическими утверждениями. С помощью интерпретации прошлого с фокусом исследовательского внимания на классовом расслоении и объяснении места казачества в истории Гражданской войны формировался новый образ казачества в общественном сознании.

Ключевые слова: истпарт, историческая память, исторический нарратив, советская идеология, Северный Кавказ, история казачества, гражданская война.

Цитирование. Клопихина В. С. Создание нарратива по истории казачества эпохи Гражданской войны на Юге России в системе советской идеологии 1920-1930-х годов // Вестник Волгоградского государственного университета. Серия 4, История. Регионоведение. Международные отношения. - 2019. - Т. 24, № 4. - С. 135147. -DOI: https://doi.org/10.15688/jvolsu4.2019.4.12

Введение. Одним из способов идеологической легитимизации власти большевиков в общественном сознании было формирование новой модели исторической памяти. Ее фундаментальным основанием являлось создание исторических нарративов, содержавших интерпретацию истории революционных событий 1917 г. и Гражданской войны в России. Для установления тотального контроля над процессом создания истории 1917-1921 гг. были организованы Истпарт и система региональных истпартов, охватывающая все пространство страны, включая Северный Кавказ. В сфере компетенции истпартов находились вопросы, связанные со сбором источников и изучением местных особенностей истории революционного движения и Гражданской войны, а также популяризация этих материалов. Истпарты являлись привилегированными институциями в системе политики памяти боль- шевиков. Они выполняли задачу выработки новой модели исторической памяти с целью воздействия на общество сверху [13].

Учитывая локальную специфику, в работе истпартов Северного Кавказа значительное внимание уделялось проблеме места и роли казачества в революционных событиях и Гражданской войне. Изучение изданий истпартов Северного Кавказа не только дает возможность реконструировать процесс создания принципиально новой историографической модели, но и позволяет определить специфику реализации в локальных нарративах установок центра, стремление соответствовать идеологической конъюнктуре. Анализ истпартовских публикаций также позволяет увидеть процесс конструирования локальной историкореволюционной концепции и определить место данных нарративов в системе советской идеологии. 
В современной России происходит процесс поиска сюжетов и интерпретаций для формирования нового конструкта исторической памяти, который смог бы выполнить функцию основы гражданской идентичности [6]. В связи с этим обращение к историческим примерам использования властного ресурса с целью конструирования новой модели исторической памяти и изучение механизма создания нарратива по истории определенных наций и социальных групп, обеспечивающего государственную идеологию, представляется актуальным.

Методы и материалы. Исследование проблемы формирования нарратива об участии казачества Дона, Кубани и Терека в Гражданской войне в качестве элемента советской идеологии проводится с методологических позиций «новой локальной истории». Это дает возможность изучить локальные способы историописания как основу формирования новой модели исторической памяти [4]. При этом под историческим нарративом понимается дискурсивный тип повествовательного текста в качестве интерпретации прошлого. Локальные исторические нарративы рассматриваются как созданные в системе работы истпартов Северного Кавказа образы прошлого. Для выявления отражения трансформации идеологических установок центра в локальных нарративах в качестве метода анализа текстов истпартовских публикаций применяется дискурсивный анализ.

В работе используется концепт «модель исторической памяти», рассматриваемый как идеологический конструкт, создававшийся в результате деятельности истпартов в качестве институциональных органов, реализующих политику памяти. По словам И.М. Салельевой и А.В. Полетаева, «историческая память» и «политика памяти» во многих случаях используются «в связке», а слово «политика» свидетельствует об изучении способов идеологизации прошлого [23, с. 53-54]. Таким образом, становится возможным изучение созданного истпартами исторического нарратива в контексте представлений о «власти историографических дискурсов», формирующих «нужные» образы в качестве официальной «памяти общества». Это, в свою очередь, позволяет установить содержание представле- ний о прошлом и раскрыть механизм их формирования.

Анализ создания нарратива по истории казачества эпохи Гражданской войны на Юге России проводится на основе наиболее значимых публикаций местных истпартов как идеологических институтов советской власти $[2 ; 3 ; 5 ; 11 ; 15 ; 18 ; 31 ; 32 ; 33]$. Вовлечение в научный оборот архивных исторических источников - делопроизводственных и инструктивных материалов, протокольной документации истпартов Северного Кавказа, отражающих методику проведения исследовательской деятельности, - позволяет выявить механизм создания нарратива в системе советской идеологии $[9 ; 10 ; 20 ; 21 ; 27 ; 30]$.

Советская и современная российская историография по проблеме участия казачества Юга России в революции 1917 г. и Гражданской войне обширна. В историографических обзорах исследований содержатся характеристики и изданий истпартов. В советской историографии публикации истпартов по истории казачества в эпоху социально-политического кризиса оценивались как «ошибочные», что соответствовало сложившемуся в 1930 -е гг. подходу, обусловленному изменением идеологической конъюнктуры после выхода в свет в 1931 г. письма И.В. Сталина «О некоторых вопросах истории большевизма» и в целом ужесточением политического режима. Это нашло отражение в работах А.И. Козлова, В.Ф. Карпова, К. Лайпанова и др. $[12 ; 14 ; 16]$.

Современными исследователями истории казачества, такими как А.А. Зайцев, Н.А. Мининков, А.П. Скорик, В.П. Трут и др. [8; 17;25; $28]$, дана взвешенная оценка публикаций истпартов. В их работах содержится информация по истории изучения казачества, свободная от идеологической конъюнктуры. Однако не всегда придается значение тому, что большинство положений, отразившихся в историческом нарративе, были детерминированы функциональными принципами и методологической парадигмой, в рамках которой происходила деятельность местных истпартов.

Территориальные рамки исследования определяются границами современных административных единиц Ставропольского края, Ростовской области, Краснодарского края. Их выбор обусловлен функционированием крае- 
вого истпарта в период 1920-1930-х гг., который координировал работу на территории ЮгоВостока России - Северного Кавказа.

Анализ. Формирование исторического нарратива об участии казачества Дона, Кубани и Терека в Гражданской войне происходило в системе работы истпартов Северного Кавказа - институциональных органов, образованных в начале 1920-х гг. с целью создания истории Октябрьской революции и Гражданской войны с точки зрения правящей партии большевиков. Именно этот фактор стал определяющим при изучении истории казачества в социально-политическом конфликте. Функционирование истпартов предусматривало проведение исследовательской работы в русле разрабатываемой в Истпарте ЦК РКП(б) ВКП(б) методологической парадигмы, которая приходила на места в виде многочисленных инструктивно-методических материалов. Кроме того, предусматривалась активная популяризация разработок истпартов с целью воздействия на общественное сознание и формирования исторической памяти на локальном уровне.

При анализе историко-революционного нарратива необходимо учитывать, что в методологических материалах центрального Истпарта уже с начала 1920-х гг. была дана установка, что при проведении исследовательской работы «не всегда окажется возможным говорить все». Кроме того, свидетельством идеологического подхода к подготовке монографий является требование «строго марксистской» оценки и применения «марксистского метода» $[19$, с. 360]. Жесткая регламентация содержания и характера источниковой базы для исследований также являлась одним из значимых факторов, определявших создание нарратива в системе формирующейся советской идеологии.

Одной из первых публикаций, в которой освещается проблема истории казачества Северного Кавказа периода Гражданской войны, была работа Г. Ладохи, изданная в 1923 г. в Краснодаре [15]. Автор провел исследование на основе собранных исторических источников Кубано-Черноморского истпарта, сотрудники которого оказывали ему активную помощь [21]. Г. Ладоха писал, что классовая дифференциация местного казачества была незначительной. Своеобразие хозяйственных условий на Кубани, по мнению автора, определило то, что казачество было зажиточным, сравнительно однородным, а процессы формирования казачьей бедноты - «пролетаризация казачества» - протекали медленно и не были существенны [15, с. 15-16]. Однако как дань идеологической конъюнктуре нарратив показывает поиск антагонизма у жителей Кубани, который исследователь видел в противостоянии и вражде между казаками и иногородним населением $[15$, с. 25$]$.

В публикации отражена и попытка осмыслить причины разгрома Красной армии во время Гражданской войны в 1918-1919 годах. Одна из них заключалась, по мысли автора, в том, что пролетариат на Кубани был незначительным по численности и, как следствие, «слабым». Поиск наличия социальной базы для революции и Гражданской войны привел Г. Ладоху к выводу, что «прекрасным революционным материалом» являлось иногороднее население. Однако для борьбы за советскую власть оно должно было быть организовано пролетариатом, чего не было сделано. Это свидетельствует о том, что возможность участия казачества в гражданском противостоянии на стороне большевиков автором не рассматривалась.

Г. Ладоха обозначил и ошибки советской власти на Кубани, например, такие как «партизанщина» и «сепаратизм», а также то, что «с самого начала не было обращено достаточного внимания на создание правильной армии, на дисциплинирование ее рядов, начиная с командного состава и кончая рядовыми красноармейцами» $[15$, с. $121-122]$. Наличие в работе Г. Ладохи обозначенных суждений приводит к пониманию того, почему книга была выпущена не под маркой истпарта. В то же время в условиях относительного плюрализма первой половины 1920-х гг., когда система советской идеологии находилась в процессе становления, ее издание еще было возможно.

С середины 1920-х гг. наблюдается тенденция установления более жесткого контроля над содержанием публикуемых работ, подчинение идеологической концепции центрального Истпарта. Сотрудниками Северо-Кавказского истпарта в Ростове-на-Дону были определены ключевые проблемы для исследовательской деятельности в это время с учетом 
локальной специфики региона: национальный, аграрный и казачий вопросы [20, л. 3]. При их изучении согласно установкам местного истпарта основное внимание должно было быть сосредоточено на истоках классовых противоречий, экономическом и политическом противоборстве, что позволило бы «подойти к истории Октябрьской революции в нашем крае» $[20$, л. 3]. Именно таким трудом должно было стать исследование по истории революции 1917 г. и Гражданской войны на Северном Кавказе Н. Янчевского [31; 32]. Отличительной чертой публикаций Н. Янчевского является то, что в них наблюдается как стремление автора следовать официальной парадигме истпартовской работы, так и желание понять особенность исторических процессов на Северном Кавказе и историю казачества в регионе.

Анализ изданий Северо-Кавказского истпарта позволяет установить специфику методов создания исторических образов в массовом сознании, в том числе образа казачества в истории страны. Так, внимание истпартов было обращено на дореволюционную историю Северного Кавказа. Под пером истпартовских сотрудников она представала в «темных тонах», выявлялись исключительно негативные черты в историческом развитии как некоторых народов Северного Кавказа, так и всего региона в целом. Анализ логики повествования позволяет увидеть, что такой подход преследовал цель продемонстрировать существование местных политических и социально-экономических причин революции для доказательства, что революция не была привнесена «извне» на Северный Кавказ, то есть из центральных регионов России.

Например, в исследовании Н. Янчевского подчеркиваются факты противостояния казачества и самодержавной власти, начиная с эпохи XVI века. Следуя идеологической парадигме, автор дает негативную оценку переселенческой политике на Северном Кавказе XIX в., рассматривая казачество уже как «орудие колониальной политики царизма». Среди социально-экономических предпосылок революции в регионе автор особо выделил «остро» стоявший национальный вопрос. Также он проанализировал социальные проблемы и «земельные» вопросы $[31$, с. $3,4,8]$.
Интересна интерпретация Н. Янчевского проблемы классовой дифференциации казачества, которая позднее не нашла развитие в советской историографии. Нарратив отражает желание автора следовать марксистской методологии, определяющей классовую борьбу как основу исторического развития, а также стремление обосновать закономерность революционных преобразований на локальном уровне. Именно это, очевидно, привело к тому, что Н. Янчевский у казачества выделил антагонистические классы накануне революционных событий 1917 г., создавая тем самым новый образ казачества. Автор дифференцировал казачество на три группы. Первая группа: незначительная «по своему весу» часть - «беднейшее казачество», которая «пошла в ногу с Октябрьской революцией». Вторая группа: «казачье дворянство», экономически представлявшее из себя «класс помещиков», заключившее союз с Добровольческой армией. Третья группа: подавляющее большинство казачества, интересы которого выражала Кубанская Рада в дни Деникина, пытавшееся идти по собственному «казачьему» пути [31, с. 117, 146]. Подчеркивая «контрреволюционность» «казачьего дворянства», Н. Янчевский писал, что именно оно выступало инициатором образования в октябpe 1917 г. «Юго-Восточного союза казачьих войск, горцев Кавказа и вольных степных народов» [31, с. 131].

В публикации Н. Янчевского также встречается и другая дифференциация казачества, осуществленная по двум основаниям. Первое основание - возраст казаков. Согласно этому критерию автор разделил казачество на стариков, относящихся к «лагерю контрреволюции», и молодых, представлявших «революционный лагерь». Второе основание для дифференциации - участие казаков в Первой мировой войне - позволило ему выделить «фронтовое» казачество в качестве одной из значимых сил революции и «остальное» казачество, переходившее чаще всего в лагерь контрреволюции [31, с. 166, 192]. По сути Н. Янчевский пишет о «расколе» казачества на противостоявшие классы в качестве местных причин социально-политического кризиса не накануне революции 1917 г., а во время Гражданской войны. 
Несмотря на наличие в нарративе обозначенных классовых дифференциаций казачества, достаточно специфичных по своему содержанию и отражающих желание следовать идеологической конъюнктуре, в качестве главных факторов Гражданской войны на Северном Кавказе Н. Янчевский определил национальный и земельный вопросы. Автор на историческом материале продемонстрировал, что главной проблемой был земельный вопpoc. Его суть заключалась в том, что в регионе накануне и во время самой революции началась борьба за землю. На Дону и Кубани эта борьба развернулась между казачеством и иногородними, на Тереке - между казачеством и горцами [31, с. 188]. Также в своей работе Н. Янчевский утверждал, что на Северном Кавказе именно сословная борьба между казаками и «иногородними» заслоняла классовый антагонизм, что является отражением стремления исследователя осмыслить специфику революционного процесса в регионе. Однако далее испартовский сотрудник отмечал, что осенью 1918 г. в регионе началась классовая борьба, сменившая существовавшую здесь ранее национальную вражду [31, с. 71]. Таким образом, публикации Н. Янчевского демонстрируют желание автора следовать методологической концепции центра и руководствоваться соответствующими установками, поступающими из Истпарта ЦК ВКП(б). Но наряду с этим в его текстах нашли отражения суждения, не ограниченные идеологической парадигмой.

Труд Н. Янчевского по истории Гражданской войны на Северном Кавказе, изданный в 1927 г., был назван Истпартом ЦК ВКП(б) как «полуисследовательская работа», которая была «в достаточной степени документированная» [30]. Было подготовлено сокращенное изложение этого исследования, и в 1931 г. издан краткий очерк [33]. Формально его публикация объяснялась тем, что большой объем и научная форма изложения исследования Н. Янчевского 1927 г. делали его недоступным для широких масс читателей. Однако в новое издание были внесены изменения и дополнения по истории казачества и колониальной политики, проблеме «аграрного вопроса», сделанные в соответствии с новой идеологической конъюнктурой, обусловленной началом проведения в 1930 г. политики сплошной коллективизации.

Анализ публикации Н. Янчевского 1931 г. показывает наличие в ней утверждений о том, что на Северном Кавказе уже накануне революционных потрясений 1917 г. интенсивно происходил процесс классового расслоения у казачества, крестьянства и «иногородних». При этом все обозначенные слои сельского населения были дифференцированы на кулачество, середняков и бедняков [33, с. 10-11]. Н. Янчевский попытался представить фактические сведения для подтверждения данного идеологического тезиса. Так, он привел статистические данные для доказательства классового расслоения. Однако, несмотря на то что они относились только к истории казачества Дона, автор на их основе сделал выводы и о дифференциации казачества Кубани и Терека.

Следовательно, местным исследователям, с одной стороны, нужно было избегать простого нанизывания фактов, отражающих локальную специфику исторического развития, на центральные схемы, которые в виде инструктивных материалов присылались на места. С другой стороны, существовала опасность не реализовать установки центра о важности связи местных фактов с общероссийской историей $[33$, с. 7]. Анализ нарратива демонстрирует, что особенность истории революционного движения в регионе не всегда получалось инкорпорировать с предлагаемой схемой. Это было обусловлено как своеобразием местной истории, так и отличием картины мира жителей Северного Кавказа от жителей других регионов России.

Истории казачества в революционных событиях 1917 г. и Гражданской войне посвящены работы другого сотрудника СевероКавказского краевого истпарта И. Борисенко. В качестве главной цели своего исследования он обозначил «изображение движущих сил революции», которые послужили причиной создания в 1918 г. на Северном Кавказе Советских республик $[2 ; 3]$. Автор считал, что при изучении данной проблемы приоритетной является «правильная» оценка этих движущих сил, критерием которой должно выступать соответствие марксистской методологии. Анализ публикации позволяет определить, что ключевой задачей данного нарратива являлось 
B.C. Клопихина. Создание нарратива по истории казачества эпохи Гражданской войны на Юге России

утверждение легитимности власти большевиков в общественном сознании с помощью интерпретации дореволюционной истории региона как «безрадостного существования». Объективность и неизбежность революционного переворота доказывались на основе негативного предреволюционного социально-экономического развития Северного Кавказа.

Повествование И. Борисенко отражает и несоответствие идеологической концепции, отраженной в методологических инструкциях и схемах, присылаемых на места Истпартом ЦК ВКП(б) - Институтом В.И. Ленина. В основе этой концепции находилось утверждение о гегемонии пролетариата в революции 1917 года. Однако И. Борисенко писал о том, что из-за слабо развитой промышленной базы на Кубани, Тереке и Ставрополье пролетариат был немногочисленным. Ввиду этого пролетарское руководство аграрно-крестьянским движением было незначительным. Следствием являлась, по мысли автора, слабость местной партийной организации большевиков [3, с. 129]. А сами большевики не смогли контролировать стихийное массовое движение [3, с. 133].

Данные выводы основывались на анализе собранной местными истпартами источниковой базы, которая демонстрировала факты из истории революционного движения на локальном уровне, отличавшиеся от официальной интерпретации событий. Однако И. Борисенко также в работе занят поиском классовой дифференциации на Северном Кавказе. Именно в расслоении казачества он увидел причину «политического раскола» внутри донского казачества.

Таким образом, несмотря на стремление местных авторов выполнять исследования на основе методологии центра, в публикациях истпартов вплоть до начала 1930-х гг. нашли отражение реалии предреволюционной истории Северного Кавказа, не ограниченные идеологической конъюнктурой. Позднее эти черты абсолютно исчезли из историко-революционного нарратива в угоду официальной идеологии. Этот процесс был постепенным, но изменения можно увидеть уже в конце 1920-х годов.

Так, текст И. Борисенко показывает попытку дистанцироваться от выводов Г. Ладохи, работу которого он использовал в своем исследовании. Например, И. Борисенко, рас- сматривая крушение советской власти в начале Гражданской войны, указывал в качестве причин этого события не малочисленность пролетариата и слабость самого движения или отсутствие у местного населения авторитета Красной армии и большевиков. Главным фактором он считал, что революции на Северном Кавказе «пришлось иметь дело не только и не столько с местной, сколько с силами внешней контрреволюции» [3, с. 225-226].

Руководители Северо-Кавказского истпарта уже в 1930 г. осознавали, что определенные суждения, которые нашли отражение в историко-революционного нарративе И. Борисенко, не соответствовали формируемой модели исторической памяти. По этой причине в предисловии к изданию от истпарта были перечислены недостатки работы. Тем не менее отсутствие других обобщающих научных работ привело к тому, что краевой истпарт допустил труд И. Борисенко к печати. Он даже получил гриф учебного пособия «для учащихся и учащихся ВУЗ'ов, техникумов и школ повышенного типа края» [2; 3].

В 1930-е гг. произошло изменение содержательных аспектов конструирования новой модели исторической памяти и исторического нарратива как ее основы, связанное с утверждением единоличной власти И.В. Сталина и трансформацией идеологической парадигмы. Исходной точкой для этого процесса являлась публикация в октябре 1931 г. письма И.В. Сталина «О некоторых вопросах истории большевизма» в журнале «Пролетарская революция» [26]. Как свидетельствуют источники, после выхода в свет этого письма по инициативе областных и краевых комитетов ВКП(б) в спешном порядке были пересмотрены издания региональных истпартов.

Одним из примеров подобного рассмотрения является совместное партийное собрание Горского научно-исследовательского института, Института по подготовке кадров, Института марксизма-ленинизма и фракции общества историков-марксистов, состоявшееся 28 ноября 1931 г. в Ростове-на-Дону. На собрании рассматривалась проблема «о положении и задачах на историческом фронте» в связи с письмом И.В. Сталина. Ход и результаты обсуждения были опубликованы в местной газете «Молот» под названием «За 
большевистскую партийность в исторической науке» [7].

Основная критика на этом собрании была обращена на книги Н. Янчевского и И. Борисенко, изданные Северо-Кавказским краевым истпартом. Сотрудникам истпарта вменялось в вину наличие многочисленных ошибок в их публикациях. В частности, Н. Янчевскому и И. Борисенко было предъявлено обвинение в том, что интерпретация национального вопроса проведена ими с антиленинских позиций, так как на Северном Кавказе национальные проблемы они поставили выше классового антагонизма. Кроме того, их работы были осуждены за наличие в них «правооппортунистической теории революционности кулачества», за игнорирование во время Гражданской войны на Северном Кавказе классового расслоения, за характеристику «двуликости» Октября. А И. Борисенко был также обвинен в «смазывании роли партии и пролетариата» в Октябрьской революции [7].

Местные руководители и активисты в результате подобных обсуждений публично каялись в допущенных ошибках. Например, заведующий Северо-Кавказским краевым истпартом А. Лиманский публично признал на этом собрании, что не продемонстрировал «достаточной бдительности», издавая работы истпарта. Н. Лихницкий, под редакцией которого было опубликовано исследование И. Борисенко, написал заявление. В нем с использованием идеологем эпохи ужесточения политико-идеологического режима 1930-х гг. говорилось о том, что в книге сделано большое количество «грубейших троцкистских и правооппортунистических» ошибок, «идущих по линии смазывания и принижения руководящей роли пролетариата и его большевистской партии, игнорирования классового расслоения казачества, преувеличение национальных противоречий и отрыв их от классовых» [9].

Подобные «заявления» стали в это время обыденным явлением. В декабре 1931 г. Северо-Кавказский краевой комитет ВКП(б) принял постановление «О ходе проработки письма И.В. Сталина». В нем сообщалось о том, что труды Н. Янчевского содержат троцкистские установки, а работы И. Борисенко являются образцом «научной халтуры» [5].
На I-й краевой конференции Северо-Кавказского филиала Всероссийского общества старых большевиков (ВОСБ) в январе 1932 г. на основе установок И.В. Сталина были обозначены приоритетные задачи работы общества. В их числе была указана необходимость «введения» чистоты в партийную историю, при исследовании которой нужно было «вскрывать и отсекать все неправильности, всякое проникновение чуждых партийной истории взглядов» $[27$, л. 3]. Пристальное внимание на конференции было обращено и на содержание работы Северо-Кавказского краевого истпарта. Вся предшествовавшая научно-исследовательская и издательская деятельность истпарта в регионе была подвергнута тотальной критике. В том числе истпарт был обвинен в искажении истории революционного движения. Эти высказывания относились, в первую очередь, к научной деятельности Н. Янчевского и И. Борисенко.

Эти историки были вскоре репрессированы. В 1932-1933 гг. Н. Янчевский был исключен из партии. Ввиду того что в это время сотрудниками истпартов могли быть только члены ВКП(б), он был также отстранен от работы в истпарте. В условиях начала 1930-х гг. это еще не было связано с угрозой физической жизни, и Н. Янчевскому удалось восстановиться в партии. Однако разрешения продолжить работу в истпарте он не получил и являлся корреспондентом в местных газетах «Молот» и «Колхозная правда». Но в эпоху Большого террора Н. Янчевский был расстрелян. Это произошло, по информации его дочери, полученной ею уже в 1990-е гг., 7 августа 1937 года. Он обвинялся в подготовке террористической организации убийства деятелей Советского государства [17, с. 251]. Заведующий Северо-Кавказским краевым истпартом А. Лиманский был также расстрелян [17, c. 265]. И. Борисенко в 1934 г. был осужден за «антисоветскую деятельность» $[8$, с. 12].

Публикации истпартов 1930-х гг. были написаны на основе противопоставления работам репрессированных исследователей, объявленным «ошибочными». Одним из подобных нарративов стал, например, сборник статей Азово-Черноморского истпарта (образован после территориальных реорганизаций) [18]. Текст публикации построен на основе 
опровержения суждений И. Борисенко и Н. Янчевского. В частности, в сборнике содержится отрицание положений, что сословные противостояния между иногородними и казаками на Северном Кавказе заменяли классовую борьбу. Но это опровержение сделано декларативно, без приведения доказательств, с помощью описания социально-экономических предпосылок Октябрьской революции в регионе, основанных на центральной схеме.

В анализируемом сборнике истпарта мы видим появление новых идеологических интерпретаций истории казачества. Так, в нем было обозначено существование на Северном Кавказе двух видов классовых противоречий. Первая разновидность классовой борьбы между верхами и низами казачества. Причем низы казачества согласно тексту являлись несколько видоизмененным классом крестьянства, а потому выступали совместно с иногородним крестьянством [1, с. 14]. Второй вид классовых противоречий - «между батраками и беднотой внутри казачества и иногородних, с одной стороны, и обуржуазившимися казаками и кулацкими элементами среди иногородних - с другой» [1, с. 14].

Таким образом, освещение сложности и неоднозначности исторического процесса в регионе на основе научного анализа исторических источников заменялось «правильными» идеологическими постулатами, а реальная историческая картина в угоду этим постулатам идеологемами. Такими идеологемами с начала проведения политики сплошной коллективизации в 1930-е гг. являлись категории «кулаки», «середняки» и «бедняки». По словам современного исследователя Д.М. Фельдмана, целенаправленное использование терминовидеологем является средством управления массовым сознанием [29, с. 9].

В сборнике Азово-Черноморского истпарта критике подвергались не только теоретические интерпретации, но и данные источников периода Гражданской войны, опубликованные местными истпартами в 1920-е годы. Например, новым «требованиям» не соответствовала информация исторического источника эпохи Гражданской войны, напечатанного в одном из сборников Донским истпартом в начале 1920 -х годов. Речь идет о докладе от 28 сентября 1918 г. одного из участников ут- верждения советской власти на Дону С. Васильченко председателю ВЦИК Я. Свердлову о работе Донского советского правительства. С. Васильченко в нем писал, что Гражданская война на Дону «носит не столько характер непосредственной классовой борьбы, сколько характер бытового антагонизма между казаками и крестьянами» [22, с. 70].

Реабилитация образа казачества в Гражданской войне связана с политической кампанией «за советское казачество» 1935-1936 гг. [24]. В опубликованной в г. Пятигорске пропагандистской брошюре «Казачество под большевистским знаменем» подчеркивалось, что «в классовом отношении казачество не было однородным» [11]. В соответствии с этим подходом выделялись «офицерско-кулацкая верхушка», «среднее» и «маломощное» казачество. Обращалось внимание, что в Гражданской войне существовала не только «казачья контрреволюция», но можно найти примеры «революционных выступлений среднего казачества, образцы борьбы за советскую власть революционных казаков в рядах Первой конной армии» [11, с. 31].

Отражение кампании «за советское казачество» в работе истпартов демонстрирует анализ переработанного и детализированного плана Азово-Черноморского истпарта на 1936 год. Он позволяет увидеть, как менялся ракурс работы истпартов при конструировании исторического нарратива в системе формирования новой модели исторической памяти на локальном уровне в соответствии с идеологической конъюнктурой. Так, истпарт занимался подготовкой очерка «С. Орджоникидзе на Дону и Кубани в 1918-1921 гг.». Ведущей задачей этой работы должно было стать изучение истории партийных организаций Дона и Кубани, характеристика их работы в масcax в эпоху Гражданской войны. Кроме того, фокус внимания должен был быть сосредоточен на освещении значения деятельности С. Орджоникидзе в истории борьбы за освобождение казачества Дона и Кубани [10].

Результаты. В 1920-е гг. истпартами Северного Кавказа был создан исторический нарратив как результат реализации политики памяти. Учитывая локальную специфику, в нем нашла отражение интерпретация истории казачества Дона, Кубани и Терека в условиях 
социально-политического кризиса эпохи Гражданской войны. Сконструированный нарратив не отличался наличием целостной непротиворечивой концепции. Это обусловлено тем, что в официально формируемой модели исторической памяти как идеологическом конструкте, где базовым сюжетом выступало обязательное изображение классовой дифференциации и борьбы, не всегда укладывались фактические данные по местной истории. В связи с этим в локальном нарративе нашли отражение суждения, не соответствовавшие создаваемой идеологической концепции истории Октябрьской революции и Гражданской войны. Это было обусловлено тем, что формирование официальной теории об историческом процессе еще не было окончено, а эра относительного плюрализма в рамках системы до конца не завершилась.

Однако уже в изданиях 1920-х гг. очевидна тенденция подчинения исследовательского поиска целям демонстрации существования региональных социально-экономических причин революции. Это происходило как результат стремления легитимизировать в общественном сознании местных жителей революционные преобразования на Северном Кавказе. Кроме того, желание установить причины «контрреволюционности» казачества приводило к тому, что дореволюционная история и проблема участия казаков в Гражданской войне искажались.

В 1930-е гг. в условиях трансформации политической системы, связанной с установлением единоличной власти И.В. Сталина, и изменения идеологической конъюнктуры созданный ранее нарратив по истории казачества как часть локального историко-революционного нарратива был объявлен «ошибочным» и попал под запрет. С этой целью была проведена кампания по дискредитации идей и сюжетов, которые уже нашли отражение на страницах публикаций истпартов Северного Кавказа.

В это время наблюдается попытка создания нарратива, отражавшего такие образы прошлого, включая историю казачества, которые бы отвечали требованиям сталинского руководства и новой идеологической конъюнктуре. Интерпретация истории казачества с фокусом внимания на поиске классовой диф- ференциации, которая нашла описание в локальном историческом нарративе, с началом проведения политики сплошной коллективизации в 1930-е гг. определялась не отражением реалий дореволюционного исторического развития региона, а применением терминов-идеологем с целью воздействия на общественное сознание - кулаки, середняки, бедняки. В результате нарратив выполнял функцию трансляции идеологических сообщений, в том числе неявных. Важным являлось отражение в нем «правильных» идеологических утверждений, а не освещение на основе научного анализа источников сложности исторического процесса в регионе, включая историю казачества в эпоху социально-политического кризиса. Таким образом, интерпретация отдельных сюжетов истории выступала в качестве генерирующего компонента советской идеологии, а она в свою очередь являлась инструментом управления массами.

\section{СПИСОК ЛИТЕРАТУРЫ}

1. Бойков, С. Социально-экономические предпосылки революции / С. Бойков // Октябрь на Северном Кавказе. - Ростов н/Д : Азово-Черноморское краевое книгоиздательство, 1934. - С. 7-43.

2. Борисенко, И. П. Советские республики на Северном Кавказе в 1918 году / И. П. Борисенко. - Ростов н/Д : Севкавкнига, 1930. - Т. І. -270 с.

3. Борисенко, И. П. Советские республики на Северном Кавказе в 1918 году / И. П. Борисенко. - Ростов н/Д : Севкавкнига, 1930. - Т.ІІ. -271 с.

4. Булыгина, Т. А. Новая локальная история: новые исследовательские практики / Т. А. Булыгина, С. И. Маловичко // Новая локальная история. 2006. - Вып. 3. - С. 7-18.

5. Буркин, Н. Антиленинские извращения в литературе по истории Октябрьской революции и гражданской войны у горских народов / Н. Буркин // Историк-марксист. - 1934. - № 2. - С. 89-90.

6. Герман, Р. Э. Историческое прошлое как компонент нормативно-символической сферы политики / Р. Э. Герман // Ученые записки Российского государственного социального университета. 2011. - № 3. - C. 69-74.

7. За большевистскую партийность в исторической науке // Молот. - 1931. - 3 дек. (№ 3132). - С. 2.

8. Зайцев, А. А. Региональный политический процесс в условиях Гражданской войны 19171922 гг:: на материалах Дона и Кубано-Черноморья / А. А. Зайцев. - М. : Традиция, 2009. -210 с. 
9. Заявление Н. Лихницкого от 28.12.1931 г. // Государственный архив новейшей истории Ставропольского края (ГАНИСК). - Ф. 50. - Оп. 3. - Д. 2. Л. $110-113$.

10. К плану работ истпартотдела Азово-Черноморского крайкома ВКП(б) на 1936 г. (апрель-декабрь) // Российский государственный архив социально-политической истории (РГАСПИ). - Ф. 71. Оп. 2. - Д. 219. - Л. 62.

11. Казачество под большевистским знаменем. - Пятигорск : Северо-Кавказ. краевое гос. издво, 1936. $-71 \mathrm{c}$.

12. Карпов, В. Ф. Историография ведущей роли рабочего класса на Дону и Северном Кавказе в 1917 г. / В. Ф. Карпов // Актуальные вопросы историографии Октября на Дону и Северном Кавказе : сб. ст. - Ростов н/Д : Изд-во РГУ, 1986. - С. 60-70.

13. Клопихина, В. С. Политика памяти как инструмент реализации советской идеологии в 19201930-е годы (по материалам истпартов Северного Кавказа) : монография / В. С. Клопихина. - Ставрополь : Ставролит, 2018. - 220 с.

14. Козлов, А. И. На историческом повороте / А. И. Козлов. - Ростов н/Д : Изд-во РГУ, 1977. - 214 с.

15. Ладоха, Г. Очерки гражданской борьбы на Кубани / Г. Ладоха. - Краснодар : Буревестник, 1923. $-122 \mathrm{c}$.

16. Лайпанов, К. Т. Итоги разработки истории Октября на Северном Кавказе / К.Т. Лайпанов // Актуальные вопросы историографии Октября на Дону и Северном Кавказе: сб. ст.. - Ростов н/Д : Изд-во РГУ, 1986. - С. 125-132.

17. Мининков, Н. А. Н.Л. Янчевский: историк, писатель, революционер / Н. А. Мининков. - Ростов н/Д : Изд-во ЮФУ, 2007. - 272 с.

18. Октябрь на Северном Кавказе. - Ростов-н/Д : Азово-Черноморское краевое книгоиздательство, 1934. - 160 с.

19. От Истпарта // Пролетарская революция. 1922. -№4. - С. 360-363.

20. Отчет о работе истпартотдела СевероКавказского крайкома ВКП(б) // Центр документации новейшей истории Ростовской области (ЦДНИРО). - Ф. 7. - Оп. 1. - Д. 825. - Л. 1-5.

21. Отчет о работе отдела истпарт Кубчеробласткома за 1923 г. // РГАСПИ. -Ф. 70. - Оп. 2. - Д. 192. Л. 8-9 об.

22. Пролетарская революция на Дону. Сборник 1. - Ростов н/Д : Донской истпарт, 1922. - 112 с.

23. Савельева, И. М. Социальные представления о прошлом, или знают ли американцы историю / И. М. Савельева, А. В. Полетаев. - М. : Новое лит. обозрение, 2008. -456 с.

24. Скорик, А. П. К истории одной политической кампании в 1930-е гг. / А. П. Скорик // Вопросы истории. - 2009. - № 1. - С. 87-95.
25. Скорик, А. П. Многоликость казачества Юга России в 1930-е годы: Очерки истории / А. П. Скорик. - Ростов н/Д : СКНЦ ВШ ЮФУ, 2008. - 344 с.

26. Сталин, И. В. О некоторых вопросах истории большевизма: письмо в редакцию журнала «Пролетарская революция» / И. В. Сталин // Сталин И.В. Сочинения. - М. : Гос. изд. полит. лит., 1951. T. 13. - C. 84-102.

27. Стенограмма I Краевой конференции Северо-Кавказского краевого отделения ВОСБ (январь 1932 г.) // ЦДНИРО. -Ф. 319. -Оп. 1.- Д. 8. - Л. 1-86 об.

28. Трут, В. П. Казачий излом (Казачество Юго-Востока России в начале XX века и в период революций 1917 года) / В. П. Трут. - Ростов н/Д : Гефест, 1997. - 253 с.

29. Фельдман, Д. М. Терминология власти. Советские политические термины в историко-культурном контексте : учеб. пособие / Д. М. Фельдман. - М. : ФОРУМ, 2016. - 480 c.

30. Характеристика местных истпартов. Северо-Кавказский истпарт // РГАСПИ. - Ф. 70. - Оп. 2. Д. 18. - Л. 11.

31. Янчевский, Н. Л. Гражданская борьба на Северном Кавказе / Н. Л. Янчевский. - Ростов н/Д : Севкавкнига, 1927. - Т. І. - 206 с.

32. Янчевский, Н. Л. Гражданская борьба на Северном Кавказе / Н. Л. Янчевский. - Ростов н/Д : Севкавкнига, 1927. - Т. II. -159 с.

33. Янчевский, Н. Л. От победы к победе. Краткий очерк истории гражданской войны на Северном Кавказе / Н. Л. Янчевский. - Ростов н/Д : Севкавкнига, 1931. - 78 с.

\section{REFERENCES}

1. Boykov S. Sotsialno-ekonomicheskie predposylki revolyutsii [Socio-Economic Prerequisites of the Revolution]. Oktyabr na Severnom Kavkaze [The October in the North Caucasus]. Rostov-on-Don, Azovo-Chernomorskoe kraevoe knigoizdatelstvo, 1934, pp. 7-43

2. Borisenko I.P. Sovetskie respubliki na Severnom Kavkaze v 1918 godu [Soviet Republics in the North Caucasus in 1918]. Rostov-on-Don, Sevkavkniga Publ., 1930, vol. 1. 270 p.

3. Borisenko I.P. Sovetskie respubliki na Severnom Kavkaze v 1918 godu [Soviet Republics in the North Caucasus in 1918]. Rostov-on-Don, Sevkavkniga Publ., 1930, vol. 2. 271 p.

4. Bulygina T.A., Malovichko S.I. Novaya lokalnaya istoriya: novye issledovatelskie praktiki [New Local History. New Research Practices]. Novaya lokalnaya istoriya, 2006, iss. 3, pp. 7-18.

5. Burkin N. Antileninskie izvrashcheniya v literature po istorii Oktyabrskoy revolyutsii i 
grazhdanskoy voyny u gorskikh narodov [AntiLeninist Distortions in Mountain Peoples' Literature on the History of the October Revolution and the Civil War]. Istorik-marksist, 1934, no. 2, pp. 89-90.

6. German R.E. Istoricheskoe proshloe kak komponent normativno-simvolicheskoy sfery politiki [Historical Past as a Component of the NormativeSymbolic Sphere of Politics]. Uchenye zapiski Rossiyskogo gosudarstvennogo sotsialnogo universiteta, 2011, no. 3, pp. 69-74.

7. Za bolshevistskuyu partiynost $v$ istoricheskoy nauke [For the Bolshevik Partyness in the History of Science]. Molot, 1931, December 31, no. 3132 , p. 2.

8. Zaytsev A.A. Regionalnyy politicheskiy protsess $v$ usloviyakh Grazhdanskoy voyny 19171922 gg.: na materialakh Dona i KubanoChernomorya [Regional Political Process in the Conditions of the Civil War of 1917-1922. On the Materials of the Don and Kuban Black Sea Region]. Moscow, Traditsiya Publ., 2009. 210 p.

9. Zayavlenie N. Likhnitskogo ot $28.12 .1931 \mathrm{~g}$. [Statement of N. Likhnitskiy Dated December 28, 1931]. Gosudarstvennyy arkhiv noveyshey istorii Stavropolskogo kraya (GANISK) [State Archive of Modern History of Stavropol Kray], F. 50, Op. 3, D. 2, L. 110-113.

10. K planu rabot istpartotdela AzovoChernomorskogo kraykoma VKP(b) na 1936 g. (apreldekabr) [To the Work Plan of the Istpart Department of the Azov Black Sea Region Regional Committee of the All-Union Communist Party (Bolsheviks) in 1936 (April-December)]. Rossiyskiy gosudarstvennyy arkhiv sotsialno-politicheskoy istorii (RGASPI) [Russian State Archive of Socio-Political History], F.71, Op.2, D.219, L.62.

11. Kazachestvo pod bolshevistskim znamenem [The Cossacks Under the Bolshevist Flag]. Pyatigorsk, Severo-Kavkazskoe kraevoe gosudarstvennoe izdatelstvo, $1936.71 \mathrm{p}$.

12. Karpov V.F. Istoriografiya vedushchey roli rabochego klassa na Donu i Severnom Kavkaze v 1917 g. [Historiography of the Leading Role of the Working Class on the Don and North Caucasus in 1917]. Aktualnye voprosy istoriografii Oktyabrya na Donu i Severnom Kavkaze: sb. st. [Relevant Issues of the Historiography of the October on the Don and North Caucasus. Collection of Articles]. Rostov-onDon, Izd-vo RGU, 1986, pp. 60-70.

13. Klopikhina V.S. Politika pamyati kak instrument realizatsii sovetskoy ideologii v 19201930-e gody (po materialam istpartov Severnogo Kavkaza): monografiya [Politics of Memory as an Instrument of the Soviet Ideology in the 1920s - 1930s (On the Materials of Istparts of the North Caucasus). Monograph]. Stavropol, Stavrolit Publ., 2018. 220 p.
14. Kozlov A.I. Na istoricheskom povorote [At the Historic Turn]. Rostov-on-Don, Izd-vo RGU, $1977.214 \mathrm{p}$.

15. Ladokha G. Ocherki grazhdanskoy borby na Kubani [Essays on the Civil Struggle on the Kuban]. Krasnodar, Burevestnik Publ., 1923. 122 p.

16. Laypanov K.T. Itogi razrabotki istorii Oktyabrya na Severnom Kavkaze [Results of Developing the History of the October in the North Caucasus]. Aktualnye voprosy istoriografii Oktyabrya na Donu i Severnom Kavkaze: sb. st. [Relevant Issues of the Historiography of the October on the Don and North Caucasus. Collection of Articles]. Rostov-on-Don, Izd-vo RGU, 1986, pp. 125-132.

17. Mininkov N.A. N.L. Yanchevskiy: istorik, pisatel, revolyutsioner [Yanchevsky: Historian, Writer, Revolutionary]. Rostov-on-Don, Izd-vo YuFU, 2007. $272 \mathrm{p}$.

18. Oktyabr na Severnom Kavkaze [The October in the North Caucasus]. Rostov-on-Don, Azovo-Chernomorskoe kraevoe knigoizdatelstvo, $1934.160 \mathrm{p}$.

19. Ot Istparta [From Istpart]. Proletarskaya revolyutsiya, 1922, no. 4, pp. 360-363.

20. Otchet o rabote istpartotdela SeveroKavkazskogo kraykoma VKP(b) [Report on the Work of the Istpart Department of the North-Caucasian Regional Committee of the All-Union Communist Party (Bolsheviks)]. Tsentr dokumentatsii noveyshey istorii Rostovskoy oblasti (TsDNIRO) [Documentation Centre of Modern History of Rostov Region], F. 7, Op. 1, D. 825, L. 1-5.

21. Otchet o rabote otdela istpart Kubcheroblastkoma za 1923 g. [Report on the Work of Istpart Department of the Kuban Black Sea Regional Committee of the Russian Communist Party (Bolsheviks) for 1923]. Rossiyskiy gosudarstvennyy arkhiv sotsialno-politicheskoy istorii (RGASPI) [Russian State Archive of Socio-Political History], F. 70, Op. 2, D. 192, L. 8-9 Ob.

22. Proletarskaya revolyutsiya na Donu. Sbornik 1 [Proletarian Revolution on the Don. Collection 1]. Rostov-on-Don, Donskoy istpart Publ., 1922. $112 \mathrm{p}$.

23. Savelyeva I.M., Poletaev A.V. Sotsialnye predstavleniya o proshlom, ili znayut li amerikantsy istoriyu [Social Beliefs of the Past, or Whether Americans Know History]. Moscow, Novoe literaturnoe obozrenie Publ., 2008. 456 p.

24. Skorik A.P. $K$ istorii odnoy politicheskoy kampanii v 1930-e gg. [To the History of One Political Campaign in the 1930s.]. Voprosy istorii, 2009, no. 1, pp. 87-95.

25. Skorik A.P. Mnogolikost kazachestva Yuga Rossii v 1930-e gody: Ocherki istorii [Diversity of the Cossacks of the South of Russia in the 1930s. 
B.C. Клопихина. Создание нарратива по истории казачества эпохи Гражданской войны на Юге России

Essays on History]. Rostov-on-Don, SKNTs VSh YuFU, 2008. $344 \mathrm{p}$.

26. Stalin I.V. O nekotorykh voprosakh istorii bolshevizma: pismo v redaktsiyu zhurnala «Proletarskaya revoliutsiya» [On Some Issues of the History of Bolshevism. Letter to the Editor of "Proletarian Revolution" Magazine]. Stalin I.V. Sochineniya [I.V. Stalin. Works]. Moscow, Gosudarstvennoe izdatelstvo politicheskoy literatury, 1951, vol. 13, pp. 84-102.

27. Stenogramma I Kraevoy konferentsii Severo-Kavkazskogo kraevogo otdeleniya VOSB (yanvar 1932 g.) [Shorthand Transcript of the $1^{\text {st }}$ Regional Conference of the North Caucasus Regional Branch of the All-Russian Society of Old Bolsheviks (January 1932)]. Tsentr dokumentatsii noveyshey istorii Rostovskoy oblasti (TsDNIRO) [Documentation Centre of Modern History of Rostov Region], F. 319, Op. 1, D. 8, L. 1-86 ob.

28. Trut V.P. Kazachiy izlom (Kazachestvo Yugo-Vostoka Rossii v nachale XX veka i v period revolyutsiy 1917 goda) [Cossack Crisis (The Cossacks of the South-East of Russia in the Early $20^{\text {th }}$ Century and During the Revolutions of 1917)]. Rostov-on-Don, Gefest Publ., 1997. 253 p.
29. Feldman D.M. Terminologiya vlasti. Sovetskie politicheskie terminy $v$ istoriko-kulturnom kontekste: ucheb. posobie [Terminology of Power. Soviet Political Terms in the Historical and Cultural Context. Study Guide]. Moscow, FORUM Publ., 2016.480 p.

30. Kharakteristika mestnykh istpartov. SeveroKavkazskiy istpart [Description of Local Ispart Departments. North Caucasus Istpart]. Rossiyskiy gosudarstvennyy arkhiv sotsialno-politicheskoy istorii (RGASPI) [Russian State Archive of SocioPolitical History], F. 70, Op. 2, D. 18, L. 11.

31. Yanchevskiy N.L. Grazhdanskaya borba na Severnom Kavkaze [Civil Struggle in the North Caucasus]. Rostov-on-Don, Sevkavkniga Publ., 1927, vol. $1.206 \mathrm{p}$.

32. Yanchevskiy N.L. Grazhdanskaya borba na Severnom Kavkaze [Civil Struggle in the North Caucasus]. Rostov-on-Don, Sevkavkniga Publ., 1927, vol. 2. $159 \mathrm{p}$.

33. Yanchevskiy N.L. Ot pobedy $k$ pobede. Kratkiy ocherk istorii grazhdanskoy voyny na Severnom Kavkaze [From Victory to Victory. Brief History of the Civil War in the North Caucasus]. Rostov-on-Don, Sevkavkniga Publ., 1931. 78 p.

\section{Information about the Author}

Vasilina S. Klopikhina, Candidate of Sciences (History), Associate Professor, Department of Historical Disciplines and Methods of Teaching, Stavropol State Pedagogical Institute, Lenina St., 417A, 355029 Stavropol, Russian Federation, vasklo@mail.ru, https://orcid.org/0000-0002-5051-6107

\section{Информация об авторе}

Василина Сергеевна Клопихина, кандидат исторических наук, доцент кафедры исторических дисциплин и методики их преподавания, Ставропольский государственный педагогический институт, ул. Ленина, 417A, 355029 г. Ставрополь, Российская Федерация, vasklo@mail.ru, https://orcid.org/0000-0002-5051-6107 